http://dx.doi.org/10.11646/phytotaxa.158.3.2

\title{
A new species and a new combination of Iris subgenus Scorpiris (Iridaceae) from Central Asia (Hissar Range, Pamir-Alai)
}

\author{
TOJIBAEV SH. KOMIL \& TURGINOV ORZIMAT \\ Institute of Gene Pool of Plants and Animals of the Academy Sciences of Uzbekistan 100125, Durmon yuli str., 32 Tashkent, \\ Uzbekistan; E-mail: ktojibaev@mail.ru
}

During floristic surveys in the southwestern borders of the Hissar Mountains (Pamir-Alai system, Central Asia), 2011-2013, we collected one unidentified species from genus Iris Linnaeus (1753: 38) subgenus Scorpiris, section Juno (Trattinnick 1817: 135) Bentham ex Bentham \& Hooker (1883: 687). These plants were introduced into the Tashkent Botanical Garden, where we carefully studied them in the Iris living collection. We conclude that the new species is related to an alliance that contains Iris parvula (Vvedensky 1963: 425) Hall \& Seisums (2011:300). This group consists primarily of high-mountain species, the distribution of which is limited to the ridges of the PamirAlai and western Tien-Shan (Central Asia) - Iris parvula, I. linifolia (Regel 1935: 152) Fedtschenko (1905: 159), I. tadshikorum (Vvedensky 1935: 152) Vvedensky (1935: 563) and I. narynensis Fedtschenko (1905: 159; Ikinci et al., 2011). According to our studies, this group could be extended by the inclusion of Iris vvedenskyi Nevski (1932: 323) and Juno linifoliiformis Khalkuziev (1985: 1663), here transferred to Iris. Iris vvedenskyi is primarily documented for the Kugi-Tang Range (western Pamir-Alai), and its main distribution is in Turkmenistan. The lesser-known I. linifoliiformis grows on northern slopes of the Turkestan and Alai Ridges (Khalkuziev, 1985). The world checklist of selected plant families (2013) placed J. linifoliiformis in synonymy with I. linifolia. Vvedensky (1971), in the note to Iris linifolia, wrote that plants from the Alai Ridge differ from I. linifolia and should be recognized as a new species, between typical I. linifolia and northern forms of I. tadshikorum Vved. Later, a researcher of the flora of Alai Ridge, Khalkuziev (1985), described these plants as Juno linifoliiformis Khalkusiev (1985: 1663) and distinguished them from I. linifolia by their deeply dissected (1.5-2.0 $\mathrm{mm}$ long) crests and narrower leaves not exceeding flowers.

The study of Ikinci et al. (2011) included a new species referred to as Iris aff. parvula (Tadjikistan: Hissar Range, near the village of Takob), which is close to where our material was collected in the Uzbekistan part of the Hissar Range, and its diagnostic characters also are similar to those of our new species.

\section{Iris khassanovii Tojibaev \& Turginov, sp. nov. (Fig. 2)}

Diagnosis: The new species differs from I. parvula in falcate leaf blade gradually narrowing apically (not straight with parallel margins and suddenly narrowing apically), white, not green, flowers, entire (not dissected) crest. From I. tadshikorum, it differs in white, not violet, flowers and entire (not dissected) crest; from I.linifolia, in white, not yellow, flowers.

Type:-UZBEKISTAN. Pamir-Alai: border of the Hissar Range, Baisuntau, near the village of Gumatag, Parakhnaursaj, stony slopes, 2123 m, N 38.35696 E 067.33598, 4 May 2013. Turginov 1421 (TASH!).

Perennial bulbous herb. Bulb ovoid, $1.0-1.5 \mathrm{~cm}$ in diameter, tunics papery, brownish. Stem 5-10 $\mathrm{cm}$ high. Leaves with internodes inconspicuous at anthesis but elongating later, falcate, linear-lanceolate, acuminate, with white margins; lowest leaf 4-10 mm wide. Flowers 1 (2), whitish with violet veins (in herbarium specimens, flowers are whitish-yellowish-green and the violet veining is no longer visible); perianth tube $4 \mathrm{~cm}$ long, yellowish-green; claw (haft) of outer tepals (falls) $4-5 \mathrm{~mm}$ wide, with parallel margins and parallel violet veining; blade of outer tepals 6$7 \times 10-12 \mathrm{~mm}$, wider than the claw, with violet veining and a violet patch. Raised crest white, denticulate, with a yellowish zone either side. Inner tepals (standards) 6-7 mm long, acute, trilobed, with central lobe 2-3 times or more longer than lateral ones, with violet veining. Petaloid style branches each with two symmetrical broad violet stripes. 
Geographically, these species are primarily from the Pamir-Alai, although some do extend into the Tien-Shan. The study of living plants in nature and herbarium specimens in TASH, LE and MW shows that this group consists of about seven species: I. parvula s.s., I. tadshikorum, I. khassanovii, I. vvedenskyi, I. linifolia, I. linifoliformis and I. narynensis. Some other species in the D2 clade (Ikinci et al. 2011), such as divergent Iris magnifica (Vvedensky 1941: 518) Khassanov \& Rakhimova (2012: 178), are more distantly related to this group and can be differentiated by their expanded (winged) claws of the outer tepals and stems with more obvious internodes at or after anthesis, characters that can also be observed in three closely related species: I. hippolyti (Vvedensky 1941: 519) Kamelin (1981: 102), I. svetlanae (Vvedensky 1971: 322) Hall \& Seissums (2011: 300) and I. maracandica (Vvedensky 1963: 426) Wendelbo (1975: 216), which may have winged claws to their outer tepals up to $2.5 \mathrm{~cm}$ wide. However, in the locus classicus of Iris hippolyti in the southeastern part of the Kyzyl-Kum Desert, Mt. Koktscha, we collected some plants without winged claws, which were close to I. narbutii Fedtschenko (1941: 515). Iris narbutii and its relative I. warleyensis Foster (1902: 386) also occupy a more distant position in clade D2, despite both species having outer tepals without expanded claws; they do not belong to the Iris parvula group (Ikinci et al., 2011).

A combination in Iris is made here for Juno linifoliiformis Khalkuziev

Iris linifoliiformis (Khalk.) Tojibaev \& Turginov, comb. nov; basionym: Juno linifoliiformis Khalkuziev, Bot. Journ. Acad. Sci. URSS, 70, 12: 1693-1695 (1985).

Distribution:-Turkestan, Alai ranges. Tadjikistan, Uzbekistan.

\section{Acknowledgements}

We would like to thank Tony Hall for his critical reading of the manuscript and helpful comments. We also thank the curators of LE and MW.

\section{References}

Bentham, G. \& Hooker, J.D. (1883) Iris. In: Genera plantarum, III. Black, London, pp. 681-702.

Fedtschenko, O. (1905) I. narynensis. Izvestia Imperatorskogo St.-Peterburgskogo Botanicheskogo Sada 5: 159.

Foster, M. (1902) Iris warleyensis Foster. In: Gardeners Chronicle (1902) III, 31: 386-387.

Hall, T. \& Seisums, A. (2011) Iris parvula (Vvedensky) Hall \& Seisums. In: Ikinci \& al. (2011) Molecular phylogenetics of the juno irises, Iris subgenus Scorpiris (Iridaceae), based on six plastid markers. Botanical Journal of the Linnean Society 167: 281-300. http://dx.doi.org/10.1111/j.1095-8339.2011.01176.x

Ikinci, N., Hall, T., Lledo, M. D., Clarkson, J., Tillie, N., Seisums, A., Saito, T., Harley, M. \& Chase, M. W. (2011) Molecular phylogenetics of the juno irises, Iris subgenus Scorpiris (Iridaceae), based on six plastid markers. Botanical Journal of the Linnean Society 167: 281-300. http://dx.doi.org/10.1111/j.1095-8339.2011.01176.x

Kamelin, R.V. (1981) Iris hyppolyti (Vved.) Kamelin. In: Takhtajan A.L. (ed.), Redkie Izchezayushie vidi flori SSSR 2, p. 102.

Khalkuziev, P. (1985) A new species of the genus Juno (Iridaceae) from northern Pamir-Alai. Botanical Journal 70: $1663-1665$.

Khassanov, F.O. \& Rakhimova, N. (2012) Taxonomical revision of genus Iris L. (Iridaceae Juss.) in the flora of Central Asia. Stapfia 97: $121-126$.

Linnaeus, C. (1753) Species plantarum. Salvii, Stockholm, 560 pp.

Mathew, B. (1997) Subgenus Scorpiris. In: Species Group of the British Iris Society (ed.). A guide to species irises: their identification and cultivation. Cambridge University Press, Cambridge, pp. 225-278.

Nevski S.A. (1932) Iris vvedenskyi Nevski. In: B.A. Fedtschenko \& M.G. Popov (eds.) Flora Turkmenia 1: 323.

Tillie, N., Chase, M.W. \& Hall, T. (2000) Molecular studies in the genus Iris L.: a preliminary study. Annali di Botanica (Roma) n.s. 1: $105-112$.

Vvedensky, A.I. (1935) Iris L. sect. Juno. In: Komarov V.L. (ed.) Flora SSSR. Akademiya Nauk, Leningrad, pp 424-439.

Vvedensky, A.I. (1935) Iris tadshikorum (Vved.) Vvedensky. Bulletin de'l Universite de`l Asie Centrale 21:152.

Vvedensky, A.I. (1971) Juno Tratt. In: Vvedensky A.I. \& Kovalevskaya S.S. (eds.) Opredelitel rastenij Srednej Azii. Tashkent: FAN, 2: 132-139, incl. Appendix: 321-322.

Wendelbo, P. (1975) Iris maracandica (Vvedensky) Wendelbo. Botaniska Notiser 128: 216.

Wendelbo, P. \& Mathew M. (1975) Iris L. In: Rechinger K.H. (ed.) Flora Iranica. Akademische Druck und Verlagsanstalt, Graz, 112 : $13-68$. 